\title{
IMPLEMENTATION OF ROOT CAUSE ANALYSIS METHOD TO INVESTIGATE FAILURE OF FRONT WALL TUBE BOILER
}

\section{PENERAPAN METODA ROOT CAUSE ANALYSIS UNTUK MENGINVESTIGASI KERUSAKAN DARI PIPA KETEL UAP BAGIAN FRONT WALL}

\author{
Eka Febriyanti ${ }^{1}$, Amin Suhadi ${ }^{1}$, Laili Novita Sari ${ }^{1}$ \\ ${ }^{1}$ National Laboratory for Structural Strength Technology \\ Agency for the Assessment and Application of Technology \\ e-mail: eka.febriyanti@bppt.go.id
}

\begin{abstract}
Root cause analysis is a method that observes all of the possible causes that make the system or components fail. This research is implemented such a method to investigate the failed front wall tube on the boiler. The purpose of this research is to find out the main cause of failure on the front wall tube to avoid a similar problem in the future. Considering all aspects that have the potential to be the main cause of failure, therefore, many tests and examinations are done, including visual tests, fractography, metallography, chemical analysis, hardness test, SEM, and EDS analysis. Examination result on the fracture surface shows two bulges on a tube and some longitudinal cracks spread on bulges outside the surface area. At the same time, the thick scale is also found on the inside surface of these bulges. Moreover, microstructure and hardness changes are also found in this area. From the analysis of all test result that obtained it is concluded that the main cause of failure is the presence of scales which reduce heat transfer so that local overheating occurred. Consequently, its tensile strength in this area is decreased, and finally, the tube could not support operational pressure and deformed to make a bulge.
\end{abstract}

Keywords: Root cause; Failure; Front wall; Tube; Boiler

\begin{abstract}
Abstrak
Root cause analysis adalah sebuah metode yang mempertimbangkan semua kemungkinan yang dapat menjadi penyebab suatu kerusakan. Penelitian ini menerapkan metode tersebut untuk menganalisa kerusakan dari front wall tube pada sebuah ketel uap. Tujuan dari penelitian ini adalah untuk menemukan penyebab utama dari kerusakan dari front wall tube agar dapat segera dilakukan tindakan perbaikan dan dapat dihindari kerusakan yang sama pada masa mendatang. Dengan mempertimbangkan seluruh aspek yang berpotensi menjadi penyebab utama kerusakan, maka berbagai pengujian dilakukan meliputi pemeriksaan visual, fraktografi, metalografi, analisa komposisi kimia, uji kekerasan, analisa dengan SEM dan EDS. Hasil pemeriksaan pada permukaan tube yang rusak menunjukkan adanya penggelembungan pada salah satu bagian tube dan pada daerah tersebut terdapat retakan longitudinal. Sementara itu pada bagian dalam daerah tersebut terdapat kerak yang tebal. Selain itu ditemukan juga terjadinya perubahan struktur mikro dan nilai kekerasan di daerah tersebut. Dari analisa terhadap semua hasil pemeriksaan dapat disimpulkan bahwa penyebab utama kerusakan adalah terbentuknya kerak yang dapat mengurangi transfer panas, sehingga terjadi pemanasan setempat. Akibatnya kekuatan tarik tube di daerah tersebut menurun sehingga tidak mampu lagi menahan tekanan operasi dan terjadi penggelembungan.
\end{abstract}

Kata Kunci : Penyebab utama; Kerusakan; Front wall; Tube; Boiler

Received: 22 April 2020, Revised: 20 July 2020, Accepted: 23 July 2020 


\section{INTRODUCTION}

When an important component on a system fails, the whole system will be shut down. If this system is a production system in a company, the potential big loss of the company will be high. Therefore, repairing or replacement of components should be done immediately to make the system working again. However, quick replacements or improper repair due to less information about the main cause of failure may even get worse; another failure can happen again in a short period of operation ${ }^{1)}$. Therefore, detail and correct failure analysis should be done to avoid similar failure reoccur in the future. There are so many methods to conduct failure analysis, but the most popular and complete method is the "root cause analysis method"2). Root cause analysis is a method that observes all of the possible causes that can make the system or components fail ${ }^{2,3}$. By considering all aspects that have the potential to be the main cause of failure therefore many data should be collected, including the chronology of failure, operational records, operational parameters, and also some examinations and tests on the failed component.

This research aims to implement the correct method to investigate the failure of the front wall tube using the root cause analysis method so that immediate action to repair in a good way can be done and similar failure can be avoided in the future.

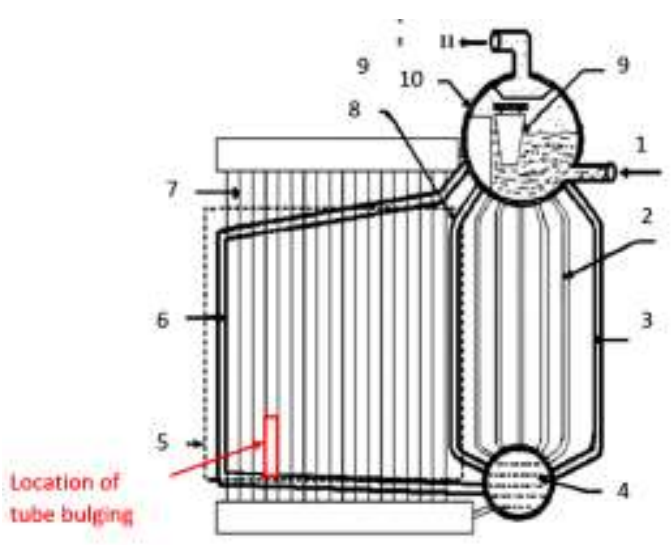

Figure 1.

Position of front wall tube which failed (red square with red arrow).

Note :

1. Feedwater inlet

2. Vertical tube bundles

3. Downcomer

4. Water drum

5. Furnace

6. Lateral D-screen tube

7. Front wall tube
8. Internal screen

9. Separator

10. Steam drum

Front wall tubes (sometimes called wall panels) are components of a boiler which has a function to transfer heat from fire outside tubes into media inside of tubes, so that good heat transfer is required. Any obstacle which blocks heat transfer will affect the boiler process and even the tube itself $f^{4,5}$. These tubes constructions are a complicated structure; as a result, routine inspection is difficult to be done. The front wall tube which failed is in a position as described in Figure 1. The identification of the fail front wall tube is recorded as tube number 24 . The tube was cut out around the leakage and then taken to the laboratory for research and tests.

\section{MATERIALS AND METHODS}

The specimens are taken out from front wall tubes, which are failed on-site location, as shown in Figure 1. Front wall tube normally made of intermediate carbon steel in ASME/ASTM standard specification ${ }^{6}$. Technical and operational data are listed in Table 1.

Table 1.

Technical data of Front Wall Tube

\begin{tabular}{ll}
\hline Tube identification & front wall tube no. \\
& 24 \\
\hline Material & SA 192 \\
Cabin boiler Temp $\left({ }^{\circ} \mathrm{C}\right)$ & $700-900$ \\
Design pressure $\left(\mathrm{kg} / \mathrm{cm}^{2}\right)$ & 42 \\
OD $\varnothing$ tube $(\mathrm{mm})$ & 76.1 \\
Tube thickness $(\mathrm{mm})$ & 3.6 \\
Inside fluid & Condensate \\
Outside fluid & Flue gas \\
Position & Fireside \\
\hline
\end{tabular}

This research is conducted based on the "root cause analysis method," where all possible sources that have contributions to failure are observed. And then, the main factor which is most dominant is further examined. Consequently, many tests and examinations are performed. The examination method includes ${ }^{2,7)}$ :

- Visual Examination

- Macrographic Examination

- Metallographic Examination

- Chemical Composition Identification

- Hardness Testing

- Scanning Electron Microscope (SEM)

- Energy-dispersive X-ray analysis (EDX) 


\section{Visual Examination}

Visual examination is performed to identify failure mode and to determine the initial area of failure, which is then selected to be a specimen for deeper examination. This method is conducted by examining the condition and contour of surface failure accurately, and then it is documented by a digital camera. Failed front wall tube was visually examined and photographed in as-received condition.

\section{Macrographic Examination}

Together with a visual examination, the macrographic examination is conducted to identify the initial crack on the surface failure of the tube investigated using stereo optical macroscope so that the area can be exposed at a higher magnification than visual examination. As a result, more information can be obtained.

\section{Metallographic Examination}

The metallographic examination is conducted to investigate more detail on initial failure and surrounding area concern with microstructure and its evolution during boiler operation, and also investigates the possibility of the micro void, micro crack, or other micro discontinuities that may exist and affects the cause of failure. The result is then documented by a digital camera.

\section{Chemical Composition Identification}

To examine elements content using spark spectrometer on the base material of the front wall tube and then compare it with composition as specified in the material standard for SA 192.

\section{Hardness Test}

Hardness tests are done to confirm the material with the specified classification and to evaluate the possibility of hardness value change, which may affect the cause of failure. The hardness test was conducted by Vickers Franc Finotest hardness tester.

\section{Scanning Electron Microscopy (SEM)}

To conduct the deeper examination on surface failure area, especially at the initial failure by SEM to find valuable information that can't be obtained by optical a microscope.

\section{Energy Dispersive X-ray analysis (EDX)}

To identify the elements present on the failure surfaces, which may have a contribution to the formation of initial failure.

\section{RESULTS AND DISCUSSIONS}

\section{Research Results \\ Visual and Macrographic Examination}

Visual and macrographic examination result shows that front wall tube investigated has two bulges side by side in close distance (Figure 2).

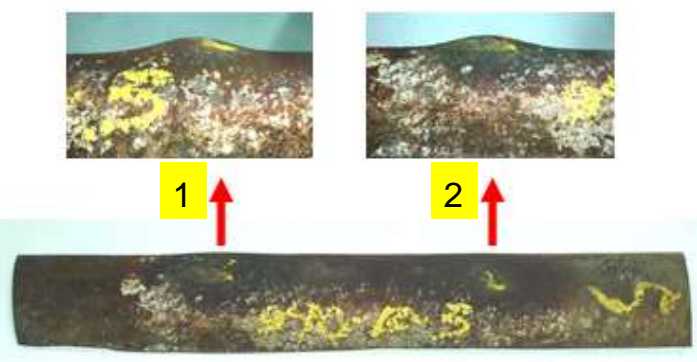

Figure 2.

Bulging on locations 1 and 2 of fail tube investigated.

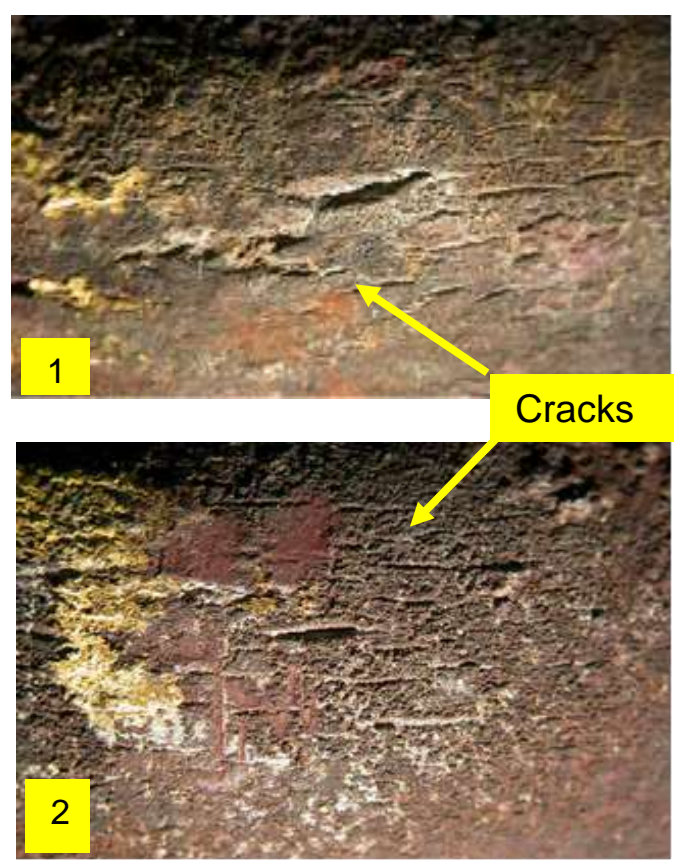

Figure 3

Longitudinal cracks on bulges outer surface on location bulge 1 and 2 .

Further macro fractography examination on the bulge area, it is found that there are many longitudinal cracks on the outer surface of the bulges (Figure 3). All of the cracks are close to each other and have a parallel direction with the tube axis. This kind of crack is typical of cracks that are formed in brittle 
material ${ }^{8}$. In fact, the tube material is low carbon steel, which is not brittle material. Therefore it can be concluded that the base material on the bulge area has already been oxidized to become steel oxide, which usually brittle $^{9)}$. Some of the big cracks are propagated and penetrated into the inner tube until the tube leak (Figure 4). Deeper examination on the inner surface of the bulges, it is found that there are thick black and white scale exist and covered the whole area of the bulge (Figure 5). This scale can reduce heat transfer from outside to the media inside the tube ${ }^{10}$.

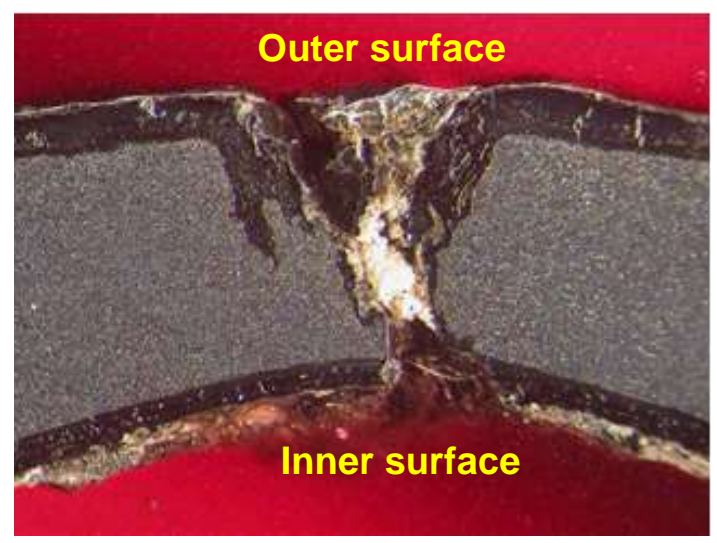

Figure 4.

Crack from the outer surface that penetrates to inner surface on bulge area.

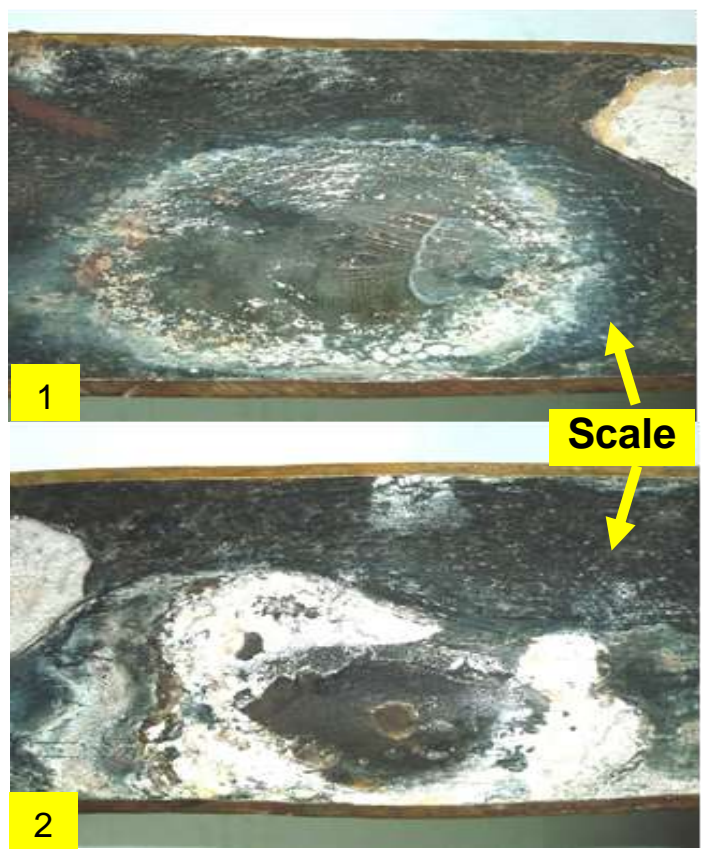

Figure 5.

Black and white scale that formed on the inner surface of bulges on location bulge 1 and 2 .

\section{Metallographic Examination}

For deeper analysis by metallographic examinations, some specimens are taken from a different area on the front wall tube, either on the bulge area or on an area that is away from the bulge. The specimen which is taken from the area away from the bulge area is used for microstructure comparison. The microstructure of this area can be seen in Figure 6. The structure is conformed to the normal microstructure of low carbon steel structure, which consists of a ferrite matrix with some lamellar pearlite spread around the matrix. However, there are many microstructure changes in the bulge area, as can be seen in Figure 7 and Figure 8. Some of the grains are grown (Figure 7), and lamellar pearlite becomes spheroidized pearlite (Figure 8).

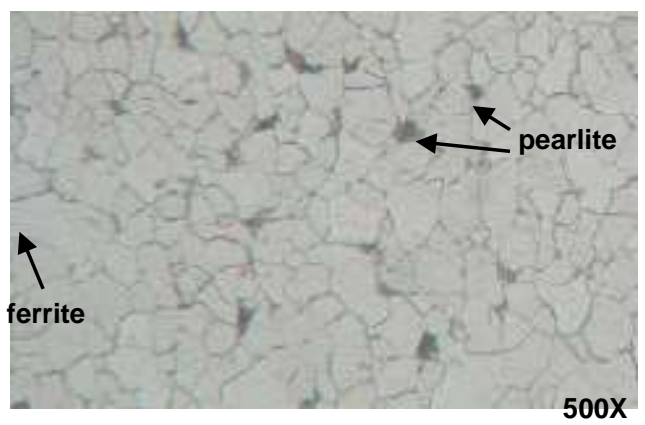

Figure 6.

The microstructure of the specimen is located away from the bulge, which consists of a mixture of ferrite (bright) and pearlite (dark). Etched by: $2 \%$ Nital.

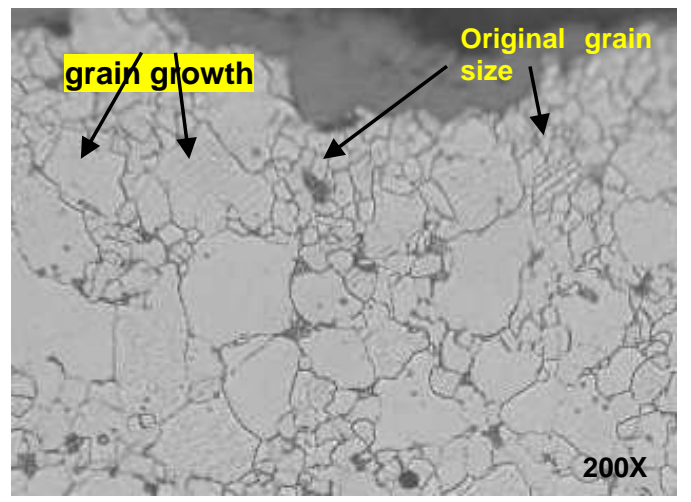

Figure 7.

The microstructure of the specimen located on the bulge. Some grains are grown. Etched by: $2 \%$ Nital.

The change of microstructure is evidence that there was local overheating occur in this area ${ }^{11)}$. Moreover, the change of microstructure can also have a significant effect on the mechanical properties of the tube. Tensile strength and hardness value will be 
decreased with the presence of bigger grain size as well as spheroidized pearlite ${ }^{12)}$.

Another result that can be obtained from metallographic examination of the cross-section in the bulge area is the presence of scale on the inner surface (Figure 9). This scale can be formed due to the attachment of some particles that occur during long term operation ${ }^{13)}$. The scale that has lower heat conductivity than steel has a significant effect of heating transfer from the outside tube into the condensate that flows in the inner tube ${ }^{14)}$.

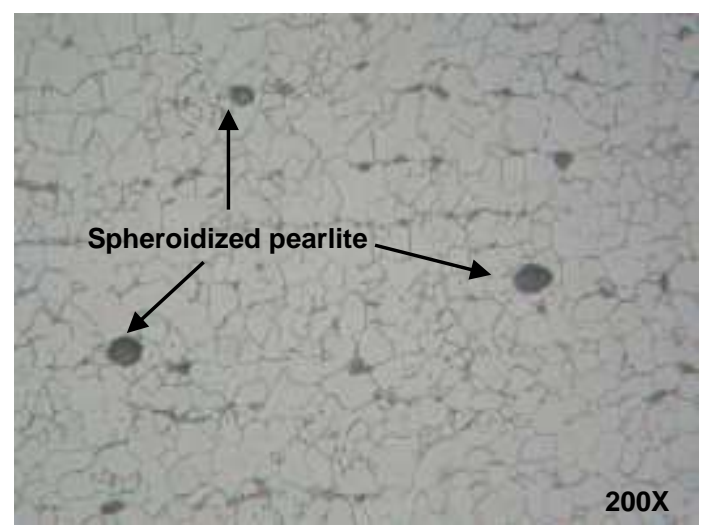

Figure 8.

The microstructure of the specimen located on the bulge area indicated that some lamellar pearlites are transformed into spheroidized pearlites. Etched by: 2\% Nital.

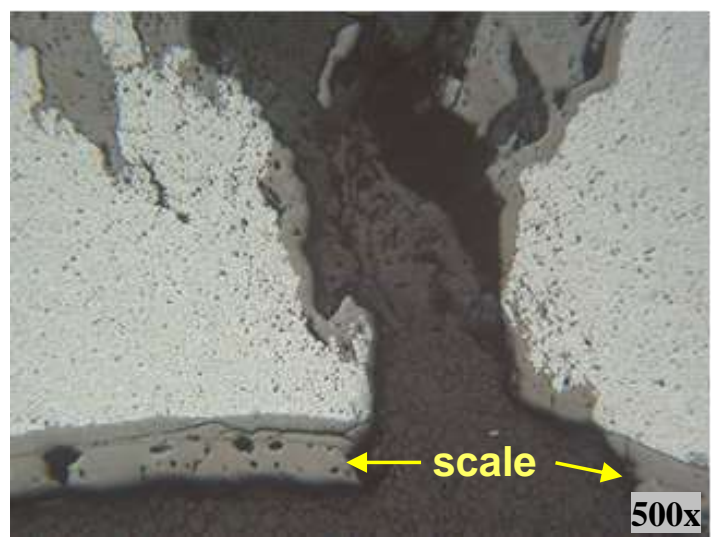

Figure 9.

The microstructure of the specimen on the cross-section of the bulge area shows a scale attached to the inner surface of the tube. Etched by: $2 \%$ Nital.

\section{Chemical Composition Analysis}

Specimen for chemical analysis is taken from the failed tube. Results of the chemical test can be seen in Table 2. This table indicated that the tube has a composition following ASTM SA 192 specification ${ }^{6}$.
It can be seen from Table 2 that there are no suspicious elements that can degrade its material characteristic of this tube.

Table 2.

Result of chemical test on failed tube

\begin{tabular}{clc}
\hline Element & $\begin{array}{l}\text { Tube } \\
\text { (wt \%) }\end{array}$ & $\begin{array}{c}\text { SA 192 } \\
\text { specification }\end{array}$ \\
\hline $\mathrm{Fe}$ & Rem. & Rem \\
$\mathrm{C}$ & 0.065 & $0.06-0.18$ \\
$\mathrm{Si}$ & 0.235 & 0.25 max. \\
$\mathrm{Mn}$ & 0.438 & $0.27-0.63$ \\
$\mathrm{~S}$ & 0.005 & 0.035 max. \\
$\mathrm{P}$ & 0.008 & 0.035 max. \\
\hline
\end{tabular}

\section{Hardness Testing}

Hardness testing results on the cross-section of tubes can be seen in Table 3 . The location of the indentation can be seen in Figure 10.

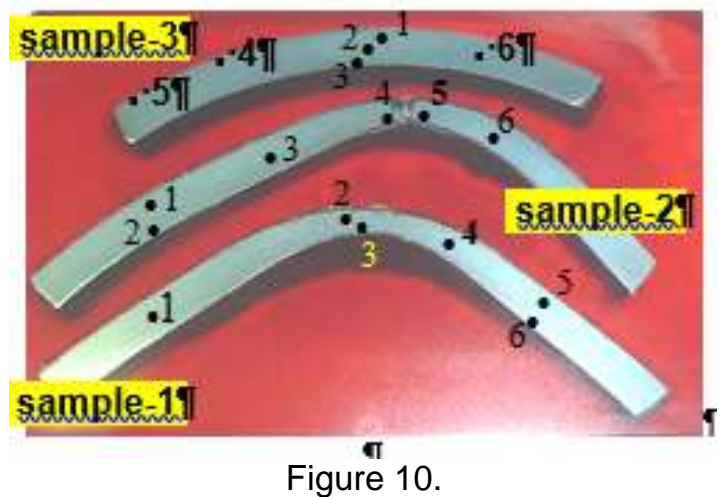

Samples for the hardness test. Samples 1 and 2 around the bulge area while sampling 3 away from the bulge. The numbers are representing the point of indentations.

Table 3.

The hardness test result of the failed tube on sample-1, 2, and 3 around the bulge area

\begin{tabular}{cccc}
\hline \multirow{4}{*}{ No. } & \multicolumn{3}{c}{ Hardness Vickers (HV) } \\
& Sample-1 & Sample-2 & Sample-3 \\
\hline 1 & 131 & 130 & 129 \\
2 & 99 & 111 & 130 \\
3 & 101 & 115 & 136 \\
4 & 106 & 98 & 138 \\
5 & 121 & 100 & 136 \\
6 & 122 & 134 & 138 \\
The hardness standard for SA 192 is 141 \\
\hline
\end{tabular}

From this table, it can be seen that in general, the hardness properties of this tube are decreased from the original specification 
for SA 192 material, and the highest decreased is achieved around the bulge. This phenomenon confirms that local overheating has occurred in the bulge area. Because tensile strength is proportional to hardness, therefore tensile strength of this area is also decreased ${ }^{2,4)}$.

\section{Scanning Electron Microscopy (SEM)}

For a deeper examination of surface failure, a specimen is taken on the bulge area, especially on the leakage surface, for scanning electron microscopy analysis. The result of this examination can be seen in Figure 11.

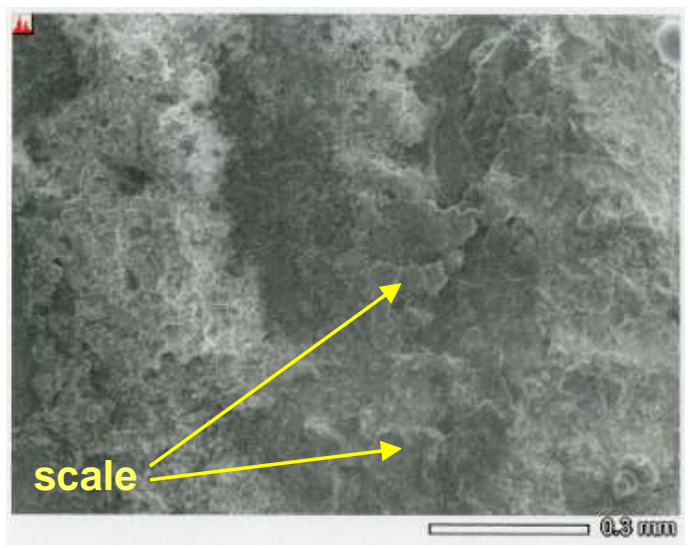

Figure 11.

Photograph of scanning electron microscopy examination result on leakage surface.

From Figure 11, it can be seen that the leakage surface is covered by scale and rust; there is no evidence of fatigue or creep fracture or other mechanical damage can be found.

\section{Energy Dispersive X-ray Analysis (EDX)}

Specimen taken for EDX examination is the same as for SEM so that the examination is focused on the surface of the failed tube. Results of this examination can be seen in Figure 12 and Table 4.

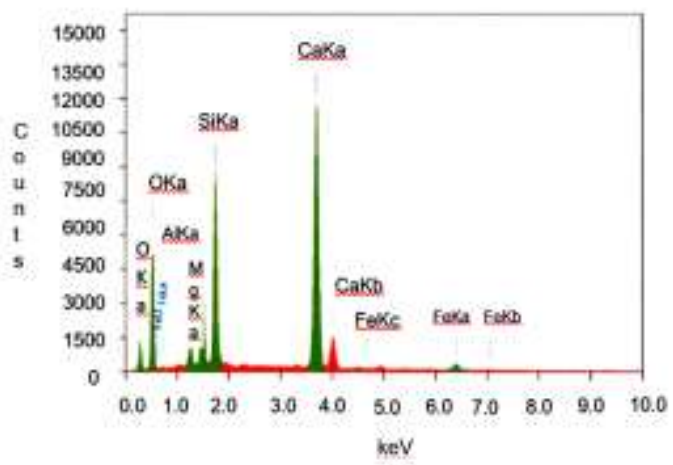

Figure 12.
EDX spectrum on leakage surface shows the elements' content in this area.

Table 4

The chemical testing result on EDX spectrum.

\begin{tabular}{cc}
\hline Elements & Weight (\%) \\
\hline $\mathrm{C}$ & 10.76 \\
$\mathrm{O}$ & 48.16 \\
$\mathrm{Mg}$ & 1.67 \\
$\mathrm{Al}$ & 4.71 \\
$\mathrm{Si}$ & 10.82 \\
$\mathrm{Ca}$ & 22.41 \\
$\mathrm{Fe}$ & 6.398 \\
$\mathrm{~V}$ & 0.95 \\
\hline
\end{tabular}

Figure 12 and Table 4 show that the dominant elements in this area are $\mathrm{O}, \mathrm{C}, \mathrm{Si}$, and $\mathrm{Ca}$. All of those elements represent the scale that formed around the leakage.

\section{Discussions}

From chemical test result indicated that the failed tube is following ASTM SA 192 specification. Therefore the failure of this front wall tube is not caused by wrong material selection.

Examinations result of macro fractography shows that the type of failure is bulging with some longitudinal cracks on the outside surface, which one of those cracks penetrated the inside of the tube to form a leakage. This type of failure is typical of failure caused by long term local overheating ${ }^{8,9,15)}$. Local overheating can be generated when carbon or low alloy steel components is prolonged exposure to exceeding their allowable temperature. In this condition, it can result in several kinds of material microstructural degradation, including grain growth, carbide coarsening and/or spheroidization, and occasionally graphitization ${ }^{2}$. At higher temperatures, the lamellar or platelet shape of carbide within the pearlite becomes unstable and gradually changes to a spheroidal shape. The internal energy of the carbide is reduced by changing its shape to a sphere. The excess surface energy is the driving force for the change, and the process that leads to the new shape is termed spheroidization. This evidence is found and presented in Figures 7 and 8 . Long-term overheating can be occurred due to the presence of scale inside the tube surface, which blocks heat transfer from the outside surface to condensate inside the tube ${ }^{2,16,17)}$. 


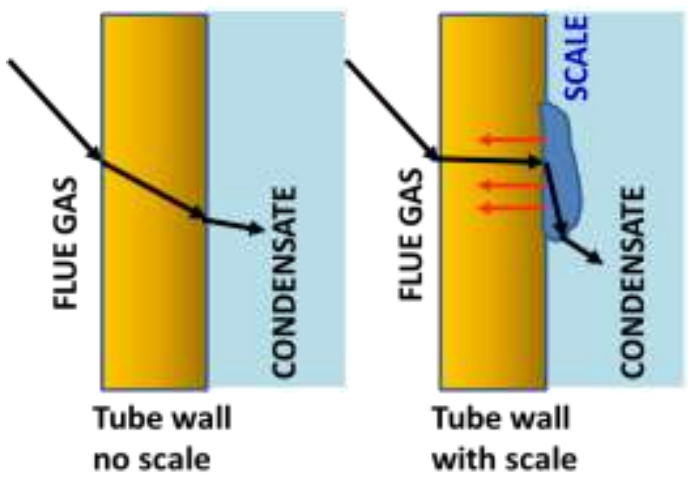

Figure 13.

Schematic figure of heat transfers between tube without scale and tube with scale.

As a result, the heat is retaining at the tube wall where the scale is attached, and consequently, this area has a higher temperature than other areas. Illustration of this phenomenon can be seen schematically in Figure 13. As local long-term overheating is taken place, microstructure degradations occur then its mechanical properties are also decreased. Therefore, this area is easy to be deformed by existing operational pressure, so that bulging followed by cracking occur. As the crack started to open, the corrosive agent may infiltrate into the tube material and reacts with the base metal to produce rust ${ }^{17)}$. As a result, crack propagation running faster and faster until leakage occurs.

\section{CONCLUSION}

Results of all testing and examination indicated that the tube investigated has material following ASTM SA 192 standard specification. Some other evidence shows that the combination of local long-term overheating and corrosion are the main contributor to the failure of the front wall tube investigated. Long term local overheating is caused by heat transfer blocking by the scale inside the tube. Local overheating produced bulging, crack, and microstructure degradation like grain growth and spheroidization of pearlite. This condition affects the mechanical properties of the tube so that cracks are formed. At the same time, the corrosive agent is easy to infiltrate into the open crack, and then corrosion reaction occurred until the tube leaks.

\section{AUTHOR CONTRIBUTIONS}

The main contributor to this work is Amin Suhadi, who is collecting data, analyzing, and writing the paper. The supporting contributor who is collecting and analyzing data and corresponding with the editor is Eka Febriyanti. At the same time, Laily Novitasari is a supporting contributor who is approving the analysis.

\section{ACKNOWLEDGMENTS}

The authors acknowledge the support of facilities and guidance for this work provided by the management of B2TKS-BPPT and all laboratory staff of AKUS-LJTKM.

\section{REFERENCES}

1. Liu, S.W., et al., Failure Analysis of the Boiler Water Wall Tube, Case Studies in Engineering Failure Analysis, Vol. 9, 2017, p. 35-39.

2. Munda, P., Kumar, S., Prakash, A. et al., Failure Investigation of Boiler Water Wall Tubes of a Thermal Power Station, J. Fail. Anal. and Preven., Vol. 16, 2016, p. 9-18.

3. Khadem Hosseini, R., and Yareiee, Sh., Failure analysis of Boiler Tube at a Petrochemical Plant, Engineering Failure Analysis, Vol. 106, December 2019.

4. Ahmad, A., Hasan, H., Noor, N.A.W.M., Lim, M.T., and Husin, S., Effect of High Temperature on Rear Pass Boiler Tubes in Coal-Fired Power Plant, American Journal of Materials Science, Vol. 5(3B), 2015, p. 5-10.

5. Sembiring, D., Widodo, D.S., Adjiantoro, B., Saman, A.B., and Kader, B.A., Failure Analysis of the Furnace Scotch Boiler, International Journal of Engineering and Advanced Technology (IJEAT), Vol. 9, Issue: 1, October 2019.

6. ASTM A192/ASME SA192, Standard Specification for Seamless Boiler Tubes, ASTM International, 2017.

7. Naumann, F.K., and Spies, F., Examination of Corroded Boiler Tubes, ASM Failure Analysis Case Histories: Power Generating Equipment, ASM International, 2019.

8. Kim, Y.S., Kim, W.C., and Kim, J.G., Bulging Rupture and Caustic Corrosion of a Boiler Tube in a Thermal Power Plant, Engineering Failure Analysis, Vol. 104, October 2019, p. 560-567. 
9. Ray, A., Raj, A., Goswami, B., and Ray, A.K., Damage Mechanism of Service Exposed Reformer Tubes in Petrochemical Industries-a Review, International Journal of Engineering and Technical Research (IJETR), Vol. 3, Issue: 10, October 2015.

10. Sanjay, P.S., and Mandloi, R. K., A Failure Analysis and Remaining Life Assessment of Boiler Water Wall tube, International Journal of Advanced Engineering Research and Science (IJAERS), Vol. 3, Issue: 7, July 2016.

11. Ardy, H., and Bangun, D.A., Failure Analysis of Superheater Boiler Tube SA 213 T12, IOP Conf. Series: Materials Science and Engineering, Vol. 547, 2019.

12. Gupta, G.K., and Chattopadhyaya, S., Critical Failure Analysis of Superheater Tubes of Coal-Based Boiler, Journal of Mechanical Engineering, Vol. 63(5), 2017, p. 287-299.

13. Henry, J., Analysis, and Optimization of Reheater Tube Failures, International Journal of Engineering Research \& Technology (IJERT), NCRAIME Conference Proceedings, 2015.
14. Sakthivel, P., Kalaimani, S., and Sasikumar, R., Analysis of Tube Failure in Water Tube Boiler, International Journal of Innovative Research in Science, Engineering and Technology, Vol. 6, Issue: 8, May 2017.

15. Karran, S.A., A Case Study on Caustic Corrosion in Refinery Piping, International Journal of Engineering and Information Technology (IIT), Vol. 3, No. 2, June 2017.

16. Awwaluddin, M., Hastuty, S., Riyandwita, B.W., Zacharias, P., and Siswanto, E., Failure analysis of boiler leakage due to caustic corrosion on Cr-Mo steel, IOP Conf. Series: Materials Science and Engineering, Vol. 536, 2019, p. 012020.

17. Zhong, J., Ke, H., Wang, X., Han, J., Wang, B., Yu, C., Huang, H., Xie, T., Wu, G., and Kang, X., Failure Analysis on High-Temperature Reheater Tube of T23 Steel in a 660 MW Thermal Power Plant Boiler, IOP Conf. Series: Materials Science and Engineering, Vol. 563, Issue: 3, 2019, p. 032002. 